\title{
Corrigendum
}

Genome Research 24: 797-808 (2014)

\section{Corrigendum: Tempo and mode of regulatory evolution in Drosophila}

Joseph D. Coolon, C. Joel McManus, Kraig R. Stevenson, Brenton R. Graveley, and Patricia J. Wittkopp

The authors would like to correct an error in Supplemental Data Set 2, which inadvertently included 40 genes that were excluded prior to the allele-specific expression analyses presented in the publication. The error does not affect the conclusions of the paper. The revised supplemental file, containing 4851 genes, is now available online.

doi: 10.1101/gr.244087.118 


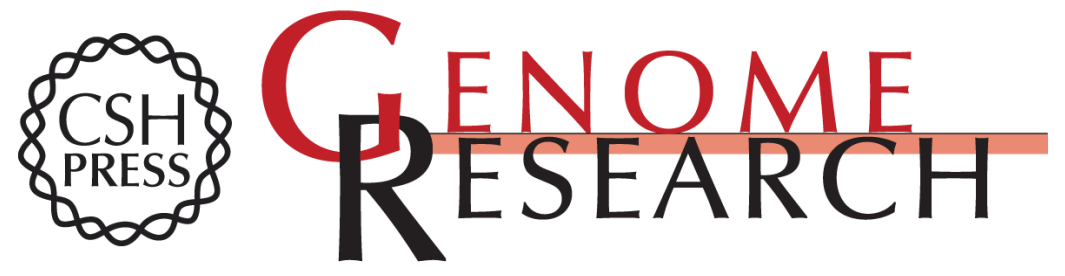

\section{Corrigendum: Tempo and mode of regulatory evolution in Drosophila}

Joseph D. Coolon, C. Joel McManus, Kraig R. Stevenson, et al.

Genome Res. 2018 28: 1766

Access the most recent version at doi:10.1101/gr.244087.118

Related Content Tempo and mode of regulatory evolution in Drosophila

Joseph D. Coolon, C. Joel McManus, Kraig R. Stevenson, et al.

Genome Res. May, 2014 24: 797-808

Open Access Freely available online through the Genome Research Open Access option.

License

Email Alerting Receive free email alerts when new articles cite this article - sign up in the box at the Service top right corner of the article or click here.

\section{Affordable, Accurate} Sequencing.

To subscribe to Genome Research go to:

https://genome.cshlp.org/subscriptions 